Br Heart J 1989;62:157-8

\title{
Fatal intrathoracic haemorrhage after cardiopulmonary resuscitation and treatment with streptokinase and heparin
}

\author{
GLENN HAUGEBERG, VERNON BONARJEE, KENNETH DICKSTEIN \\ From the Department of Cardiology, Rogaland Central Hospital, Stavanger, Norway
}

SUMMARY A 66 year old man with acute myocardial infarction underwent cardiopulmonary resuscitation before being treated with streptokinase and heparin. Seventeen hours later he died of an intrathoracic haemorrhage caused by multiple fractures of the sternum and ribs.

\section{Case report}

A 66 year old man with no previous medical history collapsed 20 minutes after the sudden onset of retrosternal chest pain. Within ten minutes the medical team arrived and started cardiopulmonary resuscitation. The patient was intubated and defibrillated three times because of ventricular fibrillation. Adrenaline was given twice for asystole. Cardiac rhythm converted to a stable accelerated nodal rhythm and the patient was taken to hospital.

The electrocardiogram on admission showed nodal rhythm, no $Q$ waves, and 3-5 $\mathrm{mm}$ ST segment elevation in leads corresponding to the inferolateral wall (I, II, III, aVF, V5, and V6). The patient was regarded as a candidate for streptokinase treatment because of the short history (two hours after onset of symptoms) and the absence of absolute contraindications. 1.5 million IU streptokinase was given over 30 minutes followed by heparin infusion (10 $000 \mathrm{IU}$ as a bolus injection and 15000 IU over 24 hours).

No other agents that are associated with bleeding complications (such as antiplatelet drugs) were given to the patient.

Initially, treatment seemed to be effective. An electrocardiogram taken 6-7 hours after admission was almost normal, with no $Q$ waves. Cardiac enzymes were measured three and $11 \frac{1}{2}$ hours after onset of symptoms. Total creatine kinase was 1375 and $4860 \mathrm{U} / 1$, creatine kinase $\mathrm{B} 76$ and $180 \mathrm{U} / \mathrm{l}$, and aspartate aminotransferase 104 and $310 \mathrm{U} / 1$ respectively.

The patient became hypotensive $12 \frac{1}{2}$ hours after admission. Shock developed and he died $4 \frac{1}{2}$ hours

Requests for reprints to Dr Glenn Haugeberg, Legekontoret, 4380 Hauge i Dalane, Norway. later. The clinical diagnosis was cardiogenic shock caused by myocardial failure.

Necropsy showed a massive intrathoracic retrosternal haemorrhage. The left thoracic cavity contained $1200 \mathrm{ml}$ blood and the right $600 \mathrm{ml}$. The necropsy results indicated that the source of haemorrhage was fracture of the sternum and fractures of the ribs (3rd, 4th, and 5 th rib on the right side and 3rd and 4th rib on the left side) which were caused by external cardiac massage. There were no signs of cardiac or pulmonary laceration. The cause of death was hypovolaemic shock.

\section{Discussion}

Intravenous streptokinase is increasingly used to treat acute myocardial infarction. Intravenous thrombolysis is effective in $50-60 \%$ of patients, ${ }^{1}$ but it is not without risks or side effects. Relative contraindications include recent external cardiac massage. $^{23}$

To our knowledge there have been no reports of fatal haemorrhage from fractures of the sternum or ribs or both after thrombolytic treatment with streptokinase and heparin. The most severe and common haemorrhages are gastrointestinal and intracranial. ${ }^{3}$

External cardiac massage is estimated to cause sternal or rib fractures in $30-45 \%$ of patients. ${ }^{45}$

The rib fractures could have been solely responsible for the fatal bleeding. It seems likely, however, that the addition of streptokinase caused this massive bleeding. Heparin was also given to this patient and others have concluded that streptokinase and heparin given simultaneously may increase the risk of haemorrhage. ${ }^{6}$

This case highlights a risk of thrombolytic treatment in patients who have undergone cardiopulmon- 
ary resuscitation. We believe that recent external cardiac massage is a relative contraindication for thrombolytic treatment and that the benefit-risk ratio must be carefully considered in patients who have had external cardiac massage.

\section{References}

1 Schröder R, Biamino G, Leitner ER, et al. Intravenous short-term infusion of streptokinase in acute myocardial infarction. Circulation 1983;67:536-48.

2 Gruppo Italiano per studio della streptochinasi nell' infarto miocardico (GISSI). Effectiveness of intravenous thrombolytic treatment in acute myocardial infarction. Lancet 1986;i:397-401.

3 Yusuf S, Collins R, Peto R, et al. Intravenous and intracoronary fibrinolytic therapy in acute myocardial infarction: overview of results on mortality, reinfarction and side-effects from 33 randomized controlled trials. Eur Heart $J$ 1985;6:556-85.

4 Klöss T, Püschel K, Wischhusen F, et al. Reanimationsverletzungen. Anästh Intensivther Notfallmed 1983;18:199-203.

5 Nagel EL, Fine EG, Krischer JP, et al. Complications of cardiopulmonary resuscitation. Crit Care Med 1981;9:424.

6 Timmis GC, Mammen EF, Ramos RG, et al. Hemorrhage vs rethrombosis after thrombolysis for acute myocardial infarction. Arch Intern Med 1986;146: 667-72. 